\title{
EDITORIAL
}

\section{Measuring exhaled nitric oxide: not only a matter of how - but also why - should we do it?}

\author{
A.T. Dinh-Xuan, J. Texereau
}

The biological functions of nitric oxide are so diverse and complex that it is now becoming increasingly difficult to delineate briefly the physiological roles and pathophysiological implications of this seemingly simple messenger molecule [1]. In respiratory medicine, NO can either be viewed as a paracrine factor (derived from endothelium, epithelium, nerves, inflammatory cells, etc), a therapeutic gas or a marker of inflammation [2]. Amongst other paracrine factors, the endothelium-derived NO has, in its own right, a central role to play in the modulation of pulmonary vascular tone [3]. As a gaseous molecule, NO has been extensively investigated in clinical settings and used as inhalational therapy to relieve pulmonary hypertension and/or refractory hypoxaemia in adults and infants [4]. Although there are many questions that still remain to be properly answered [5], the use of inhaled NO has undoubtedly revived interest in molecules that can selectively reduce both pulmonary vascular resistance and intrapulmonary shunt. As a radical molecule, NO is highly reactive and readily combines with an array of biological molecules, ranging from reactive oxygen species to haeme moiety containing proteins [6]. This explains why measurement of NO in biological systems was often fraught with difficulties in the early days [7]. Since 1991, however, measurement of in vivo NO production in humans have been proven to be technically feasible by means of ex vivo manoeuvres, i.e. by sampling the exhaled breath and analysing it for NO content using a chemiluminescent NO analyser [8]. As the technique is noninvasive, it was immediately applied to patients, especially those with bronchial asth$\mathrm{ma}$, to assess endogenous production of NO by the lung [9-11]. Soon, the accumulating evidence suggested that measurement of exhaled NO could be viewed as a new lung function test [12] to monitor airway inflammation in asthma [13] and other conditions associated with inflammation of the respiratory tract [14]. It is still difficult to know the actual source of the endogenous NO that is detected in the exhaled air [15]. As NO is synthesized by many lung cells, it could originate from virtually anywhere in the respiratory tract, from alveolar space to the nose. Several recent and carefully conducted studies have clearly shown how the techniques of measurement are likely to affect the amount and origin of exhaled NO [1620]. This prompted the European Respiratory Society, in

Service de Physiologie-Explorations Fonctionnelles, CHU Cochin, APHP \& Université Paris V-René Descartes, Paris, France.

Correspondence: A.T. Dinh-Xuan, Service de Physiologie-Explorations Fonctionnelles, Hôpital Cochin, 27 rue du faubourg Saint-Jacques, 75679 Paris cedex 14, France. Fax: 33144072538
1997, to issue specific recommendations for the measurement of exhaled and nasal NO [21], an initiative which was followed in 1998 by the American Thoracic Society.

In contrast with the ongoing technical debate on how to measure exhaled NO, it seems that a consensus has been reached on the diagnostic value of NO measurement in asthma. Compelling evidence clearly demonstrates that asthmatic subjects who are not treated with inhaled glucocorticoids have on average higher amounts of exhaled NO as compared with healthy controls [9-14, 18, 21]. The strength of the evidence, and hence the validity of the finding, is based on both practical and theoretical grounds. Higher levels of exhaled NO in asthma have been consistently found by several independent investigators using different techniques of measurement $[18,22,23]$. Theoretical considerations are also consistent with the raw data. NO is synthesized by a group of three enzymes, called NO synthases (NOS). Each isoform is differentially distributed in organs and tissues, with a preferential expression of the constitutive NOS I in neurons, the inducible NOS II in inflammatory cells and the constitutive NOS III in vascular endothelium [1]. All three isoforms have been detected in lung cells. In particular, the inducible NOS II is markedly expressed in asthmatic airways [24]. Unlike the constitutive neuronal NOS I and endothelial NOS III which synthesize NO only in minute amounts to meet physiological demands, expression of inducible NOS II by asthmatic epithelial cells leads to a massive synthesis of NO, thus explaining high levels of exhaled NO in asthma. Moreover, the inhibitory effect of glucocorticoid hormones on NO production [25-28] is supported by the molecular links between inducible NOS II, nuclear factor$\kappa \mathrm{B}(\mathrm{NF}-\kappa \mathrm{B})$ (a key transcription factor in asthma [29]) and the genomic effect of the glucocorticoids [30]. Briefly, binding of the hormone to its intracellular receptor leads to the transcription of the inhibitory subunit (IкB) which normally impedes NF- $\kappa \mathrm{B}$ binding to the promoter regions of inflammatory genes, including the gene encoding inducible NOS II [30].

It is probably true that exhaled NO is increased in asthma as a result of airway inflammation. There are several practical issues that can be inferred from this observation. Because NO production is increased in inflammatory diseases, measuring exhaled NO can therefore be viewed as a noninvasive, though indirect, means of detecting inflammation in the respiratory tract. Because NOS II is induced by several inflammatory cytokines (e.g. interleukin-1 $\beta$, tumour necrosis factor- $\alpha$, interferon- $\gamma$ ), monitoring exhaled $\mathrm{NO}$ is also an elegant way to assess the efficacy of antiinflammatory agents, assuming that the more potent the 
medication, the lower the amount of exhaled NO. Consistent with this contention is the observation of a dosedependent inhibitory effect of inhaled glucocorticoids on exhaled NO in asthmatic patients [27]. Although of considerable interest, the measurement of exhaled NO may be difficult to interpret in some instances, and there are a few questions that still need to be answered.

The first question relates to the sensitivity and specificity of the measurement of exhaled NO in detecting airway inflammation. There are at least two categories of patients in whom airways inflammation does not seem to be associated with high levels of exhaled NO. These are smokers [31] and patients with cystic fibrosis (CF) [32] who consistently have reduced exhaled NO in comparison with healthy subjects. NO and carbon monoxide are two major components of tobacco smoke. Both are putative inhibitors of NOS activity. Inhibition of NOS by cigarette smoke occurs at a post-translational level and probably accounts for the reduced NO production in smokers. The mechanism of reduced exhaled NO in CF patients is not known. Circumstantial evidence however suggests that accelerated oxidation, rather than reduced production, of $\mathrm{NO}$ is a likely mechanism responsible for the relatively low level of exhaled NO in CF patients [33]. Also, not all medications with putative anti-inflammatory properties result in a reduced exhaled NO in asthmatic patients. For example, it has been shown that the sulphidopeptide leukotriene receptor antagonists do not alter endogenous production of NO in asthmatic patients [34].

The second question relates to the physiology of endogenous NO with respect to its bronchodilatory effect. There is evidence to suggest that maintaining a certain level of NO production within the tracheobronchial tree is critical in modulating bronchial tone, especially when the airways are stimulated by bronchoconstrictor stimuli. Firstly, inhibition of NO production by various L-arginine analogues often aggravates bronchial hyperreactivity to various agents, including histamine [35], methacholine [36] and bradykinin [36]. Basal bronchomotor tone, however, does not seem to be affected by NOS inhibitors [37, 38]. Secondly, exhaled NO is increased during upper respiratory tract viral infections [39], but this increased production seems to be beneficial for asthmatic patients. This was first suggested by the demonstration that experimental virus-induced airway hyperresponsiveness was related to a relative deficiency in NO [40]. The protective role of NO in this condition is further supported by the recent finding that the greater an increase in exhaled NO, the lesser the severity of airway hyperresponsiveness to histamine following experimental rhinovirus infection in asthmatic subjects [41]. A stimulus such as nebulized spa water also causes an increase in exhaled NO which parallels an improvement of lung function in asthmatic children [42]. Evidence is therefore accumulating to suggest that endogenous NO is not only beneficial, but it may also be of particular importance when the bronchi are harmed by exogenous factors.

Such factors may simply be a strenuous exercise with its associated hyperventilation, which may cause exerciseinduced asthma in susceptible individuals [43]. In this issue of the Journal, Therminarias et al. [44] have shown that airway obstruction is associated with a relative de-crease in NO output during exercise in eight healthy subjects breathing cold $\left(-10^{\circ} \mathrm{C}\right)$ as compared with ambient $\left(22^{\circ} \mathrm{C}\right)$ air. Due to the bronchodilatory effect of NO, it is tempting to speculate that such a relative deficiency in NO production may favour the occurrence of airway obstruction in these subjects. This protective effect is further supported by the recent demonstration that the release of endogenous NO by kinins inhibits the bronchoconstriction induced by cold air inhalation in guinea pigs [45]. We must, however, keep in mind that in the study conducted by TherMinarias et al. [44], as in other studies [46-50], there is an increase from baseline of the actual NO output during exercise, even with cold air breathing. The explanation is therefore likely to be far more subtle than the mere hypothesis of a relative deficiency of a bronchodilator agent (namely endogenous NO) being responsible for the occurrence of bronchial obstruction.

There has been, during the last decade, a great deal of discussion about the putative beneficial and/or deleterious effect of NO. Even when NO seems to play a protective role as shown by THERMINARIAS et al. [44], we still have dif-ficulty in putting forward an explanation for such a putative beneficial effect. Biological mechanisms underlying the ac-tion of NO in the human body are usually a complex matter. It is likely that the same conclusion also applies to the respiratory system. If complexity often appeals to the scientists, we now understand why NO has become such as appealing topic for chest physicians during the last 10 years.

\section{References}

1. Schmidt HHHW, Walter U. NO at work. Cell 1994; 78: 919-925.

2. Singh S, Evans TW. Nitric oxide, the biological mediator of the decade: fact or fiction? Eur Respir J 1997; 10: 699-707.

3. Dinh-Xuan AT. Endothelial modulation of pulmonary vascular tone. Eur Respir J 1992; 5: 757-762.

4. Dinh-Xuan AT, Brunet F, Dhainaut JF. The use, and misuse, of exogenous endothelial-derived vasodilators in acute respiratory failure. Intensive Care Med 1997; 23: $1110-1118$.

5. Payen DM. Is nitric oxide inhalation a "cosmetic" therapy in acute respiratory distress syndrome? Am J Respir Crit Care Med 1998; 157: 1361-1362.

6. Stamler JS. Redox signaling: nitrosylation and related target interactions of nitric oxide. Cell 1994; 78: 931-936.

7. Archer SL. Measurement of nitric oxide in biological methods. FASEB J 1993; 7: 349-360.

8. Gustafsson LE, Leone AM, Persson MG, Wiklund NP, Moncada S. Endogenous nitric oxide is present in the exhaled air of rabbits, guinea pigs and humans. Biochem Biophys Res Commun 1991; 181: 852-857.

9. Alving K, Weitzberg E, Lundberg JM. Increased amount of nitric oxide in exhaled air of asthmatics. Eur Respir $J$ 1993; 6: 1368-1370.

10. Kharitonov SA, Yates DH, Robbins RA, Logan-Sinclair $\mathrm{R}$, Shinebourne EA, Barnes PJ. Increased nitric oxide in exhaled air of asthmatic patients. Lancet 1994; 343: $133-$ 135.

11. Persson MG, Zetterström O, Agrenius V, Ihre E, Gustafsson LE. Single-breath nitric oxide measurements in asthmatic patients and smokers. Lancet 1994; 343: 146-147.

12. Barnes PJ, Kharitonov SA. Exhaled nitric oxide: a new lung function test. Thorax 1996; 51: 233-237.

13. Gustafsson LE. Exhaled nitric oxide as a marker in asthma. Eur Respir J 1998; 11: Suppl. 26, 49s-52s. 
14. Lundberg JON, Weitzberg E, Lundberg JM, Alving K. Nitric oxide in exhaled air. Eur Respir J 1996; 9: 26712680.

15. Byrnes CA, Dinarevic S, Busst C, Bush A, Shinebourne EA. Is nitric oxide in exhaled air produced at airway or alveolar level? Eur Respir J 1997; 10: 1021-1025.

16. Sato K, Sakamaki T, Sumino H, et al. Rate of nitric oxide release in the lung and factors influencing the concentration of exhaled nitric oxide. Am J Physiol (Lung Cell Mol Physiol) 1996; 270: L914-L920.

17. Kimberly B, Nejadnik B, Giraud GD, Holden WE. Nasal contribution to exhaled nitric oxide at rest and during breathholding in humans. Am J Respir Crit Care Med 1996; 153: 829-836.

18. Robbins RA, Floreani AA, Von Essen SG, et al. Measurement of exhaled nitric oxide by three different techniques. Am J Respir Crit Care Med 1996; 153: 1631-1635.

19. Silkoff PE, McClean PA, Slutsky AS, et al. Marked flowdependence of exhaled nitric oxide using a new technique to exclude nasal nitric oxide. Am J Respir Crit Care Med 1997; 155: 260-267.

20. Therminarias A, Flore P, Favre-Juvin A, Oddou MF, Delaire M, Grimbert F. Air contamination with nitric oxide: effect on exhaled nitric oxide response. Am $J$ Respir Crit Care Med 1998; 157: 791-795.

21. Kharitonov SA, Alving K, Barnes PJ. Exhaled and nasal nitric oxide measurement: recommendations. Eur Respir $J$ 1997; 10: 1683-1693.

22. Massaro AF, Mehta S, Lilly CM, Kobzik L, Reilly JJ, Drazen JM. Elevated nitric oxide concentrations in isolated lower airway gas of asthmatic subjects. Am J Respir Crit Care Med 1996; 153: 1510-1514.

23. Kharitonov SA, Chung KF, Evans D, O'Connor BJ, Barnes PJ. Increased exhaled nitric oxide in asthma is mainly derived from the lower respiratory tract. Am J Respir Crit Care Med 1996; 153: 1773-1780.

24. Hamid Q, Springall DR, Riveros-Moreno V, et al. Induction of nitric oxide in asthma. Lancet 1993; 342: 15101513.

25. Massaro AF, Gaston B, Kita D, Fanta C, Stamler JS, Drazen JM. Expired nitric oxide levels during treatment of acute asthma. Am J Respir Crit Care Med 1995; 152: 800-803.

26. Kharitonov SA, Yates DA, Chung KF, Barnes PJ. Inhaled glucocorticoids decrease nitric oxide in exhaled air of asthmatic patients. Am J Respir Crit Care Med 1996; 153: 454-457.

27. Kharitonov SA, Yates DA, Chung KF, Barnes PJ. Changes in the dose of inhaled steroid affect exhaled nitric oxide levels in asthmatic patients. Eur Respir J 1996; 9: 196-201.

28. Garnier P, Fajac I, Dessanges JF, Dall'Ava-Santucci J, Lockhart A, Dinh-Xuan AT. Exhaled nitric oxide during acute changes of airways calibre in asthma. Eur Respir J 1996; 9: 1134-1138.

29. Barnes PJ, Karin M. Nuclear factor- $\mathrm{B}$ : a pivotal transcription factor in chronic inflammatory diseases. $N \mathrm{Engl}$ J Med 1997; 336: 1066-1071.

30. Barnes PJ, Adcock JM. Transcription factors and asthma. Eur Respir J 1998; 12: 221-234.

31. Kharitonov SA, Robbins RA, Yates DH, Keatings V, Barnes PJ. Acute and chronic effects of cigarette smoking on exhaled nitric oxide. Am J Respir Crit Care Med 1995; 152: 609-612.

32. Dötsch J, Demirakça S, Terbrack HG, Hüls G, Rascher W, Kühl PG. Airway nitric oxide in asthmatic children and patients with cystic fibrosis. Eur Respir J 1996; 9: $2537-2540$.
33. Linnane SJ, Keatings VM, Costello CM, et al. Total sputum nitrate plus nitrite is raised during acute pulmonary infection in cystic fibrosis. Am J Respir Crit Care Med 1998; 158: 207-212.

34. Dinh-Xuan AT, Compagnon A, Summerton L, Harris A. Attenuation of exercise-induced asthma but not exerciseinduced increases in exhaled nitric oxide output by zafirlukast. Am J Crit Care Med 1998; 157: A624.

35. Nijkamp FP, van der Linde HJ, Folkerts G. Nitric oxide synthesis inhibitors induce airway hyperresponsiveness in the guinea pig in vivo and in vitro: role of the epithelium. Am Rev Respir Dis 1993; 148: 727-734.

36. Ricciardolo FLM, Geppetti P, Mistretta A, et al. Randomised double-blind placebo-controlled study of the effect of inhibition of nitric oxide synthesis in bradykinin-induced asthma. Lancet 1996; 348: 374-377.

37. Yates DH, Kharitonov SA, Robbins RA, Thomas PS, Barnes PJ. Effect of a nitric oxide synthase inhibitor and a glucocorticosteroid on exhaled nitric oxide. Am J Respir Crit Care Med 1995; 152: 892-896.

38. Yates DH, Kharitonov SA, Thomas PS, Barnes PJ. Endogenous nitric oxide is decreased in asthmatic patients by an inhibitor of inducible nitric oxide synthase. $\mathrm{Am}$ J Respir Crit Care Med 1996; 154: 247-250.

39. Kharitonov SA, Yates DH, Barnes PJ. Increased nitric oxide in exhaled air of normal human subjects with upper respiratory tract infections. Eur Respir J 1995; 8: 295-297.

40. Folkerts G, van der Linde HJ, Nijkamp FP. Virus-induced airway hyperresponsiveness in guinea pigs is related to a deficiency in nitric oxide. J Clin Invest 1995; 8: 295-297.

41. de Gouw HWFM, Grünberg K, Schot R, Kroes ACM, Dick EC, Sterk PJ. Relationship between exhaled nitric oxide and airway hyperresponsiveness following experimental rhinovirus infection in asthmatic subjects. Eur Respir J 1998; 11: 126-132.

42. Caillaud DM, Kaufman C, Fourot-Bauzon M, Nguyen LT, Bedu M, Dinh-Xuan AT. Exhaled nitric oxide in children with mild asthma. Am J Respir Crit Care Med 1997; 155: A824.

43. McFadden ER Jr, Gilbert IA. Exercise-induced asthma. $N$ Engl J Med 1994; 330: 1362-1367.

44. Therminarias A, Oddou MF, Favre-Juvin A, Flore P, Delaire M. Bronchial obstruction and exhaled nitric oxide response during exercise in cold air. Eur Respir J 1998; 12: 1040-1045.

45. Yoshihara S, Nadel JA, Figini M, Emanueli C, Pradeles P, Geppetti P. Endogenous nitric oxide inhibits bronchoconstriction induced by cold-air inhalation in guinea pigs: role of kinins. Am J Respir Crit Care Med 1998; 157: 547-552.

46. Persson MG, Wiklund NP, Gustafsson LE. Endogenous nitric oxide in single exhalation and the change during exercise. Am Rev Respir Dis 1993; 148: 1210-1214.

47. Trolin G, Andén T, Hedenstierna G. Nitric oxide in expired air at rest and during exercise. Acta Physiol Scand 1994; 151: 159-163.

48. Iwamoto J, Pendergast DR, Suzuki H, Krasney JA. Effect of graded exercise on nitric oxide in expired air in humans. Respir Physiol 1994; 97: 333-345.

49. Maroun MJ, Mehta S, Turcotte R, Cosio MG, Hussain SNA. Effects of physical conditioning on endogenous nitric oxide output during exercise. J Appl Physiol 1995; 79: 1219-1225.

50. Phillips CR, Giraud GD, Holden WE. Exhaled nitric oxide during exercise: site of release and modulation by ventilation and blood flow. J Appl Physiol 1996; 80: 1865-1871. 